G-Strings and Sympathy 



\section{G-Strings and Sympathy}

Strip Club Regulars and Male Desire

KATHERINE FRANK

Duke University Press * Durham \& London 2002 
(C) 2002 Duke University Press

All rights reserved

Printed in the United States of

America on acid-free paper $\infty$

Designed by Amy Ruth Buchanan

Typeset in Dante by Keystone

Typesetting, Inc.

Library of Congress Cataloging-in-

Publication Data appear on the last

printed page of this book.

and printing, 2003 
In memory of

my grandfather,

John Murawski 
